5 Manun'ebo MN, Haggerty PA, Kalengaie M, Ashworth A, Kirkwood BR. Influence of demographic, socioeconomic and environmental variables on childhood diarrhoea in a rural area of Zaire. J Trop Med Hyg 1994;97:31-8.

6 Wright CE, el Alamy M, DuPont HL, Holguin AH, Hsi BP, Thacker SB, et al. The role of home environment in infant diarrhea in rural Egypt. AmJ Epidemiol 1991;134:887-94

7 Mara DD, Alabaster GP. An environmental classification of housingrelated diseases in developing countries. J Trop Med Hyg 1995;98:41-51.

8 Schofield CJ, White GB. Engineering against insect-borne diseases in the domestic environment, house design and domestic vectors of disease. Trans $R$ Soc Trop Med Hyg 1984;78:285-92.

9 Gamage-Mendis AC, Carter R, Mendis C, De Zoysa PK. Herath P, Mendis $\mathrm{KN}$. Clustering of malaria infections within an endemic population: risk of malaria associated with the type of housing construction. Am J Trop Med Hyg 1991;45:77-85.
10 Gunawardena DM, Wickremasinghe AR, Muthuwatta L, Weerasingha S, Rajakaruna J, Senanayaka T, et al. Malaria risk factors in an epidemic region of Sri Lanka, and the impact and cost implications of risk factorbased interventions. Am J Trop Med Hyg 1998;58:533-42.

11 Ko YC, Chen MJ, Yeh SM. The predisposing and protective factors against dengue virus transmission by mosquito vector. Am J Epidemiol 1992;136:214-20.

12 United Nations Habitat II Conference. Report of the United Nations conference on human settlements (habitat II). Istanbul: United Nations Development Programme, 1996.

13 World Health Organization. Urbanization and its implications for child health. Geneva: WHO, 1988

14 Genton B, Smith T, Baea K, Narara A, al-Yaman F, Beck HP, et al. Malaria: how useful are clinical criteria for improving the diagnosis in a highly endemic area? Trans R Soc Trop Med Hyg 1994;88:537-41.

(Accepted 23 January 2001)

\title{
Eligibility for home treatment of deep vein thrombosis: prospective study
}

\author{
Thomas Schwarz, Benjamin Schmidt, Ulrike Höhlein, Jan Beyer, Hans-Egbert Schröder, \\ Sebastian M Schellong
}

Editorial by Eikelboom and Baker

Department of Internal Medicine, Division of Vascular Medicine,

University Hospital

"Carl Gusta

Carus", D-01307

Dresden, Germany

Thomas Schwarz

clinical research fellow

Benjamin Schmidt

clinical research fellow

Ulrike Höhlein

medical student

Jan Beyer

clinical research fellow

Hans-Egbert

Schröder

professor

Sebastian M

Schellong

consultant

Correspondence to: T Schwarz

tho_schwarz@

hotmail.com

BMJ 2001;322:1212-3
Low molecular weight heparin is safe and effective for the treatment of deep vein thrombosis. ${ }^{1}$ We have recently shown in a randomised study that immobilisation is not necessary. ${ }^{2}$ The results challenge the traditional notion that these patients must be treated in hospital. For selected patients, outpatient treatment has been shown to be safe and effective. ${ }^{34}$ We determined the proportion of patients who still require admission to hospital and why.

\section{Methods and results}

Between 1 November 1998 and 15 August 1999 all patients presenting to the vascular diagnostics unit of the University Hospital Dresden, Germany, as outpatients with acute deep vein thrombosis in the leg were prospectively evaluated regarding eligibilty for home treatment. We defined acute deep vein thrombosis as non-compressible deep veins on ultrasonography (UM9 HDI, linear array 4-7 MHz, ATL, Bothell, Washington, DC) and symptoms that had been present for less than two weeks. Written informed consent was obtained from all patients.

On the day of diagnosis patients were started on oral anticoagulation with phenprocoumon (adjusted to a target international normalised ratio of 2-3) and the low molecular weight heparin nadroparin (90 $\mathrm{IU} / \mathrm{kg}$ body weight twice daily) until a therapeutic ratio was achieved. All patients received class II compression stockings. At presentation, the decision regarding hospital admission was based on medical reasons, home care situation, patients' and general practitioners' rejection of outpatient treatment, and hospital service logis- tics. The 95\% confidence intervals were calculated according to the Wilson procedure.

We assessed recurrent venous thromboembolism (verified by sonography, ventilation-perfusion scan, or pulmonary angiography), major bleeding, and death at clinical follow up of patients treated at home. Assessments were at three and six days and two, four, and 12 weeks after initiation of treatment. The study was approved by the local ethics committee.

A total of 117 consecutive outpatients (48 men, 69 women) were diagnosed as having acute deep vein thrombosis. Of these, 92 received home treatmentthat is, they were not admitted at all. The median (range) age was 62.0 (19-95) years. Three patients were admitted to hospital for medical reasons; 11 because of the home care situation; and 11 for reasons of hospital service logistics (table). At the 12 week follow up of the 92 patients, eight had died (six from cancer and two from chronic heart failure; three had recurrent thrombosis; and four had developed minor bleeding. No clinical pulmonary embolism or major bleeding occurred. Safety and efficacy figures are similar to those previously published.

\section{Comment}

Most outpatients presenting with acute deep vein thrombosis do not need to be admitted to hospital. The proportion who do require admission depends mainly on factors to do with infrastructure rather than medical reasons. In our study, only 3\% of patients were admitted for medical reasons, and in 9\% admission was because medication and international normalised ratio

Reasons for admission to hospital in 117 consecutive outpatients with deep vein thrombosis

\begin{tabular}{|c|c|c|}
\hline Reason for admission & No of patients $(\% ; 95 \% \mathrm{Cl})$ & Details \\
\hline Medical reason & $3 / 117(2.6 ; 0.9$ to 7.1$)$ & Massive leg swelling and severe pain $(n=2)$; concomitant pneumonia $(n=1)$ \\
\hline Home care situation & $11 / 117(9.4 ; 5.3$ to 16.1$)$ & $\begin{array}{l}\text { Self injection with heparin not possible }(n=7 \text {; poor compliance in } 5 \text {, social } \\
\text { reasons in 2); daily INR testing not possible }(n=5)\end{array}$ \\
\hline $\begin{array}{l}\text { Patient or general practitioner rejects } \\
\text { outpatient treatment }\end{array}$ & $0(0$ to 3.2$)$ & NA \\
\hline Hospital service logistics & $11 / 117(9.4 ; 5.3$ to 16.1$)$ & Presented at weekend $(n=7)$ or after $5 \mathrm{pm}(\mathrm{n}=4)$ \\
\hline
\end{tabular}


could not be monitored. Even these patients could have been treated as outpatients if adequate professional care had been available at home. No serious complications were noted in patients treated in an outpatient setting. Another 9\% of our patients presented in the emergency room and were already being treated for deep vein thrombosis suspected on clinical grounds alone. They were admitted until ultrasound examination could be performed.

We thank Roswitha Frommhold of the nursing staff for excellent patient care and Harry R Büller, Amsterdam, for his helpful criticism.

Contributors: TS and SMS had the original idea for the study, recruited a large number of patients, created the trial database, analysed the data, and wrote the paper. BS conducted statistical analysis and recruited patients. UH advised on data collection and analysed the data. JB recruited patients for the study. HES revised the final version of the manuscript and is the guarantor of the paper. All authors approved the final version of the paper.
Funding: Sanofi-synthelabo, Berlin, and medi-Bayreuth, Bayreuth.

Competing interests: None declared.

1 Dolovich LR, Ginsberg JS, Douketis JD, Holbrook AM, Cheah G. A metaanalysis comparing low-molecular-weight heparins with unfractionated heparin in the treatment of venous thromboembolism. Arch Int Med heparin in the $2000 ; 160: 181-8$.

2 Schellong SM, Schwarz T, Kropp J, Prescher Y, Beuthien B, Daniel WG Bed rest in deep vein thrombosis and the incidence of pulmonary embolism. Thromb Haemost 1999;82(suppl):127-9.

3 Koopman MM, Prandoni P, Piovella F, Ockelford PA, Brandjes DPM, van der Meer J, et al. Treatment of venous thrombosis with intravenous unfractionated heparin administered in the hospital as compared with subcutaneous low-molecular-weight heparin administered at home N Engl J Med 1996;334:682-7.

4 Levine M, Gent M, Hirsh J, Leclerc J, Anderson D, Weitz J, et al. A comparison of low-molecular-weight heparin administered primarily at home with unfractionated heparin administered in the hospital for proximal deep-vein thrombosis. N Engl J Med 1996;334:677-81.

5 Lensing WA, Prandoni P, Prins MH, Büller HR. Deep-vein thrombosis. Lancet 1999;353:479-85.

(Accepted 16 January 2001)

\section{Drug points}

\section{Pseudophaeochromocytoma syndrome associated with clozapine}

Andrew J Krentz, Southampton General Hospital, Southampton SO16 6YG, Sherine Mikhail, Paul Cantrell, Camlet Lodge Regional Secure Unit, Chase Farm Hospital, Enfield EN2 8JL, Gavin M Hill, Doncaster Royal Infirmary, Doncaster DN2 5LT

Clozapine (Clozaril, Novartis), a tricyclic dibenzodiazepine derivative, has an established role in the treatment of refractory schizophrenia. In the United Kingdom the drug may only be prescribed by consultant psychiatrists registered with the Clozaril Patient Monitoring Service; this reflects the serious adverse effect profile of the drug, which includes agranulocytosis. Paradoxical hypertension with increased concentrations of urinary catecholamines has also been reported, albeit rarely and in association with other antipsychotic treatment. ${ }^{1}$

We describe four patients with a pseudophaeochromocytoma syndrome associated with clozapine. All had serious refractory psychiatric disturbances. Case 2 presented to a cardiology clinic with hypertension for which she was receiving bendrofluazide $2.5 \mathrm{mg}$ daily, and case 3 was referred to a diabetes clinic with type 2 diabetes (treated with metformin $500 \mathrm{mg}$ twice daily) and dyslipidaemia. Case 4 was initially referred to a renal clinic with hypertension. Profuse sweating, hypertension, and obesity were common to all the patients; intermittent tachycardia was noted in cases 1 to 3 (table). Renal and hepatic function were normal in all the patients, and there was no evidence of alternative causes of secondary hypertension. The interval between the start of clozapine treatment and the development of the clinical features varied (table), being evident within one week in case 1. Urinary catecholamine concentrations, measured in 24 hour collections during clozapine treatment, were increased in all four patients (table). To exclude the possibility of phaeochromocytoma, case 1 underwent computed tomography and cases 3 and 4 underwent isotopic imaging. ${ }^{2}$ In cases 1 and 2, urinary catecholamine concentrations normalised, and clinical features improved or resolved after withdrawal of the drug; these patients also lost several kilograms in body weight. Clozapine was continued at a lower dose in case 3 as the supervising psychiatrist advised against its withdrawal. Treatment was also continued in case 4 because his blood pressure settled spontaneously.

The neuropharmacological actions of clozapine are complex and include affinity for $5-\mathrm{HT}_{2}$ receptors and for adrenergic receptors in vitro." Clozapine has been reported to cause increases in plasma noradrenaline concentrations, a postulated mechanism being the inhibition of resynaptic reuptake mediated by $\alpha_{2}$ adrenergic receptors. ${ }^{4}$ Sulpiride, which blocks presynaptic $\alpha_{2}$ adrenoreceptors, may have contributed to the clinical features in cases 2 and 4 .

We contacted the manufacturer, Novartis, and the Committee on Safety of Medicines about this adverse event

AJK thanks Dr V J Lewington, Dr Robert Peckitt, and Dr Clare Bradley for their help with case 3 and Dr Mary Rogerson for her help with case 4 .

Competing interests: None declared.

1 Li JKY, Yeung VTF, Lueung CM, Chow CC, Ko GTC, So WY, et al. Clozapine: a mimickry of phaeochromocytoma. Aust NZ J Psychiatry 1997;31: 889-91.

2 Wittles RM, Kaplan EL, Roizen MF. Sensitivity of diagnostic and localization tests for phaeochromocytoma. Arch Intern Med 2000;160:2521-4.

3 Eresbefsky L, Watanabe MD, Tran-Johnson TK. Clozapine: an atypical antipsychotic agent. Clin Pharmacol 1989;8:691-709.

4 Davidson M, Kahn RS, Stern RG, Hirschowitz J, Apter S, Knott P, et al Treatment with clozapine and its effect on plasma haemavanillic acid and norepinephrine concentrations in schizophrenia. Psychiatry Res 1993;46: 151-63.

5 Mayer RD, Montgomery SA. Acute hypertensive episode induced by sulpiride-a case report. Human Psychopharmacol 1989;4:149-50.

Clinical details of patients and catecholamine concentrations

\begin{tabular}{|c|c|c|c|c|c|c|c|c|}
\hline $\begin{array}{l}\text { Case } \\
\text { No }\end{array}$ & $\begin{array}{l}\text { Age } \\
\text { (years) }\end{array}$ & Sex & $\begin{array}{c}\text { Body } \\
\text { mass } \\
\text { index } \\
\left(\mathrm{kg} / \mathrm{m}^{2}\right)\end{array}$ & $\begin{array}{c}\text { Clozapine } \\
\text { dose (mg/day) } \\
\text { and duration } \\
\text { of treatment* }^{*}\end{array}$ & Other drugs & $\begin{array}{l}\text { Heart } \\
\text { rate } \\
\text { (beats/ } \\
\text { min) }\end{array}$ & $\begin{array}{c}\text { Blood } \\
\text { pressure } \\
(\mathrm{mm} \mathrm{Hg})\end{array}$ & $\begin{array}{c}24 \text { hour } \\
\text { urinary } \\
\text { catecholamine } \\
\text { concentration } \\
(\mu \mathrm{mol}) \\
\text { (reference } \\
\text { ) range) } \\
\end{array}$ \\
\hline 1 & 27 & Male & 31 & $\begin{array}{c}400 \text { for } \\
2 \text { months }\end{array}$ & $\begin{array}{l}\text { Fluoxetine } \\
20 \text { mg daily }\end{array}$ & 110 & $170 / 120$ & $\begin{array}{r}\text { Noradrenaline } \\
1.68(<0.59), \\
\text { vanillylmandelic } \\
\text { acid } 54(<35)\end{array}$ \\
\hline 2 & 28 & Female & 38 & $\begin{array}{c}700 \text { for } \\
12 \text { months }\end{array}$ & $\begin{array}{c}\text { Bendrofluazide } \\
2.5 \mathrm{mg} \text { daily }\end{array}$ & 104 & $\begin{array}{l}143 / \\
112 \dagger\end{array}$ & $\begin{array}{c}\text { Noradrenaline } \\
1.02 \\
(0.08-0.45)\end{array}$ \\
\hline 3 & 38 & Male & 40 & $\begin{array}{c}900 \text { for } \\
18 \text { months }\end{array}$ & $\begin{array}{l}\text { Sulpiride } 600 \mathrm{mg} \text {, } \\
\text { venlafaxine } 150 \mathrm{mg} \text {, } \\
\text { and metformin } \\
500 \mathrm{mg} \text { twice daily }\end{array}$ & 130 & $\begin{array}{r}156 / 100 \\
n\end{array}$ & $\begin{array}{c}\text { Noradrenaline } \\
0.53 \\
(0.07-0.48), \\
\text { normetadrenaline } \\
4.3(0-3.00)\end{array}$ \\
\hline 4 & 22 & Male & 30 & $\begin{array}{c}600 \text { for } \\
3 \text { months }\end{array}$ & $\begin{array}{l}\text { Sulpiride } 200 \mathrm{mg} \\
\text { daily and paroxetine } \\
50 \mathrm{mg} \text { daily }\end{array}$ & NA & $\begin{array}{r}\text { 180/120 } \\
n\end{array}$ & $\begin{array}{c}\text { Noradrenaline } \\
0.90 \\
(0.07-0.48), \\
\text { normetadrenaline } \\
4.6(0-3.00)\end{array}$ \\
\hline
\end{tabular}

$\mathrm{NA}=$ not available. ${ }^{*}$ Before measurement of 24 hour urinary catecholamine concentration. †Average during ambulatory monitoring. 